\title{
Where is the church on Monday? Awakening the church to the theology and practice of ministry and mission in the marketplace
}

\begin{tabular}{|c|c|}
\hline \multicolumn{2}{|l|}{$\begin{array}{l}\text { Authors: } \\
\text { Dion A. Forster }{ }^{1}\end{array}$} \\
\hline \multicolumn{2}{|c|}{$\begin{array}{l}\text { Affiliations: } \\
{ }^{1} \text { Faculty of Theology, } \\
\text { Stellenbosch University, } \\
\text { South Africa }\end{array}$} \\
\hline \multicolumn{2}{|c|}{$\begin{array}{l}{ }^{2} \text { Beyers Naudé Center } \\
\text { for Public Theology, } \\
\text { Unit for Innovation and } \\
\text { Transformation of Church } \\
\text { and Society, South Africa }\end{array}$} \\
\hline \multicolumn{2}{|c|}{$\begin{array}{l}{ }^{3} \text { Camino Consultancy, } \\
\text { Organisational Development } \\
\text { Specialists, South Africa }\end{array}$} \\
\hline \multicolumn{2}{|c|}{$\begin{array}{l}\text { Correspondence to: } \\
\text { Dion Forster }\end{array}$} \\
\hline \multicolumn{2}{|c|}{$\begin{array}{l}\text { Email: } \\
\text { dionforster@sun.ac.za }\end{array}$} \\
\hline \multicolumn{2}{|c|}{$\begin{array}{l}\text { Postal address: } \\
\text { Faculty of Theology, } \\
\text { Stellenbosch University } \\
\text { Dorp Street, Stellenbos } \\
\text { 7600, South Africa }\end{array}$} \\
\hline \multicolumn{2}{|c|}{$\begin{array}{l}\text { Dates: } \\
\text { Received: } 23 \text { Feb. } 2015 \\
\text { Accepted: } 22 \text { June } 2015 \\
\text { Published: } 21 \text { Aug. } 2015\end{array}$} \\
\hline \multicolumn{2}{|c|}{$\begin{array}{l}\text { How to cite this article: } \\
\text { Forster, D.A. \& Oostenbrink, } \\
\text { J.W., 2015, 'Where is } \\
\text { the church on Monday? } \\
\text { Awakening the church to } \\
\text { the theology and practice of } \\
\text { ministry and mission in the } \\
\text { marketplace', In die Skriflig } \\
\text { 49(3), Art. \#1944, } 8 \text { pages. } \\
\text { http://dx.doi.org/10.4102/ } \\
\text { ids.v49i3.1944 }\end{array}$} \\
\hline \multicolumn{2}{|c|}{$\begin{array}{l}\text { Copyright: } \\
\text { (C) 2015. The Authors. } \\
\text { Licensee: AOSIS } \\
\text { OpenJournals. This work is } \\
\text { licensed under the Creative } \\
\text { Commons Attribution } \\
\text { License. }\end{array}$} \\
\hline \multicolumn{2}{|l|}{ Read online: } \\
\hline 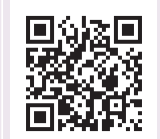 & $\begin{array}{l}\text { Scan this QR } \\
\text { code with your } \\
\text { smart phone or } \\
\text { mobile device } \\
\text { to read online. }\end{array}$ \\
\hline
\end{tabular}

Authors:

Dion A. Forster ${ }^{1,2}$

\section{Affiliations:}

${ }^{1}$ Faculty of Theology,

Stellenbosch University,

South Africa

${ }^{2}$ Beyers Naudé Cente

Transformation of Church

${ }^{3}$ Camino Consultancy,

Organisational Development

Specialists, South Africa

Correspondence to:

Email:

\section{Postal address:}

Faculty of Theology,

Stellenbosch University, 171

7600 , South Africa

Dates:

Received: 23 Feb. 2

Accepted: 22 June 2015

How to cite this article:

Forster, D.A. \& Oostenbrink, J.W., 2015, 'Where is

the church on Monday?

the theology and practice of ministry and mission in the marketplace', In die Skriflig 49(3), Art. \#1944, 8 pages. http://dx.doi.org/10.4102/ ids.v49i3.1944

Licensee: AOSIS

OpenJournals. This work is licensed under the Creative Commons Attribution License.
Recent research by the Call42 group has shown that South African Christians experience that they are not adequately prepared or equipped for Christian living and discipleship in the world of work - here called the marketplace. This article has argued for the importance of a rediscovery of a theology of work that can empower and equip the church and individual Christians for ministry in the marketplace. The article traces why such a theological deficiency exists in the South African church by considering areas such as an inadequate theology of work and mission, a dualism between faith and work, and an unbalanced emphasis on the role of clergy and a lesser focus on the role of the laity in the missio Dei. Having considered these challenges to the mission and theological identity of the church, the article discusses the three general theological views of the church in South Africa as presented by Smit and adapted by Forster. It considers how the church could become an agent of mission and transformation in the marketplace in each of these three forms. The article comes to the conclusion that the church will need to revisit its missional theology, refocuses its efforts on broader society, and empowers and equips its members for ministry in the marketplace in order to be faithful in partnering with God in the missio Dei.

Waar is die kerk op Maandag? Ontwaking van die kerk tot die teologie en praktyk van bediening en sending in die markplein. Onlangse navorsing deur die Call42 groep het bevind dat Suid-Afrikaanse Christene ervaar dat hulle nie voldoende voorbereid en toegerus is vir die Christelike lewe en dissipelskap in die arbeidsmark - hier genoem die markplein nie. Hierdie artikel poog om aan te toon dat 'n herontdekking van 'n teologie van werk belangrik is ten einde die kerk in die algemeen asook individuele Christene te bemagtig en toe te rus vir die bediening in die markplein. Hierdie artikel poog dus om die kwessie van die sodanige teologiese leemte in die Suid-Afrikaanse kerk na te vors. Terreine soos onvoldoende teologie van werk en sending word ondersoek, 'n dualisme tussen geloof en werk word uitgewys, en daar word aangetoon dat 'n oorspeling van die predikant se rol en 'n onderspeling van gewone kerklidmate se rol die kerk se betrokkenheid by die missio Dei benadeel. Met inagneming van hierdie uitdagings aan sending en die kerk se teologiese identiteit, bespreek die artikel drie algemene teologiese standpunte van die kerk in SuidAfrika, soos deur Smit aangebied en deur Forster aangepas. Die artikel besin hoe die kerk in elk van hierdie drie bestaansvorme ' $n$ agent van sending en transformasie in die markplein kan wees. Die gevolgtrekking word gemaak dat die kerk die missionale of sendingteologie moet heroorweeg, opnuut moet fokus op die uitreik na die breër gemeenskap en lidmate vir bediening in die markplein moet bemagtig en toerus. Sodoende sal die kerk getrou wees aan die medewerking met God in die missio Dei.

\section{Introduction}

This article wishes to honour the theological legacy of George Lotter by focussing on an important aspect of Christian life and witness. Work is an important part of contemporary life. Not only does it provide an opportunity for persons to earn an income to meet their survival needs, it can also be a source of great joy and creative expression, or of hardship and struggle. Moreover, if Christians were inspired and equipped to understand the potential that their presence, talents and abilities could make towards achieving the aims of God's kingdom in society, we could see a new missional thrust emerging within the church. Sadly, very few South African churches have realised the potential of a theology and practice of ministry for the church in the marketplace. 
The marketplace, ${ }^{1}$ as seen in this article, includes those sectors of life where persons are engaged in tasks described as work. It includes tasks in education, production, the delivery of services, the arts and healthcare amongst others. The point is that this location is identified by the kind of activities members are engaged in beyond the life of the gathered, worshipping, congregation or church. ${ }^{2}$ The marketplace, in this context, is where church members are when they are not 'at church' for worship services, teaching or fellowship. ${ }^{3}$ This article investigates how the church as community, and also the church as individual Christians, is called to be active in the marketplace.

There is a growing awareness that the great commission (as expressed in Mt 28:18-20) can only be successfully addressed in the environment where people spend most of their labouring and productive hours (Forster 2014a; Forster \& Power 2011:70-71; Keller \& Leary-Alsdorf 2012:19; Volf 2005;). Whilst South Africa has largely a selfidentified Christian population - as high as $85.6 \%$ (Anon 2014:32) - actual church attendance in South Africa is not very high (Nieman 2010:37). It would thus stand to reason that a sensible strategy for mission and evangelism should not be focussed only on the gathered community of the church, but should also focus on locations and settings where the majority of the population is to be found: the marketplace. Therefore, the mobilisation of marketplace Christians is essential if the Sunday-Monday gap is to be bridged and the goal of world mission is to be accomplished (Le Bruyns 2004:10).

Furthermore, the Christian is not only called to make disciples, but also to be an agent of change (salt and light Mt 5:13, 14) through whom the principles of God's kingdom such as justice, equity, human dignity, flourishing, et cetera, are to be established in society (Costa 2007:17-27; Forster \& Power 2011:47-62; Greene 2001:4-8, 2010:17-23; Silvoso 2006:104-121, 2007:15-26; Spada \& Scott 2011:20-41; Van Der Merwe et al. 2010: chapter 8).

In addition to the above, globalisation is forcing the church to think about the concerns of broader society in more effective and creative ways. These challenges include economic inequality, corruption, political and economical instability, difficult and unfair labour practices, lack of social, economic and political integrity, unethical or destructive leadership, over-exposure to information, continuous change and turmoil, unemployment, poverty and hunger, HIV and environmental degradation and a host of others. Many of

\footnotetext{
1.A variety of terms are employed in popular discourse and academic scholarship to describe the environment of work. Among the more popular descriptors are the 'marketplace' (Le Bruyns 2004:7-9; Silvoso 2006:17, 37-45), the 'sphere' or 'domain' of work (Johnson 2011:21-58) and the 'world of work' (Keller \& Leary-
} Alsdorf 2012:19-24; Spada \& Scott 2011:104-123).

2.See Smit's article (1996:119-129) for a succinct discussion of the theological understanding of the three forms of church, that is, church as gathered community or congregation, church as denomination, church as scattered community of salt and light in the world (Philander 2011:177; also see Smit 2007b:61-68). This will and light in the world (Philander 2011:177; also see Smit 2007b:61-68). This will
also be discussed in detail in the section on the different forms of church in the also be discusse
marketplace.

3.For a more detailed discussion of this understanding of category identity, refer to Volf (2005:386-387). these problems find both their genesis and their resolution in the marketplace. Persons with strong values and a robust theology that is focussed on societal engagement have the potential to be agents for change. Sadly, the reverse is frequently seen: because of an inadequate theology of faith and work or a lack of skill or support for discipleship and witness in the world of work, Christians become part of the problem. There are innumerable scandals in which Christian individuals and communities are found to be complicit in social and moral decay, economic abuse and the degradation of the common good (Batchelor 2008).

In response to this, there has been a rise of para-church movements and ministries that aim to support Christians in the marketplace. Amongst the more prominent South African examples are Unashamedly Ethical (Anon n.d.a), Alpha in the workplace (Anon n.d.b) and HalfTime (Anon n.d.c). ${ }^{4}$ The rapid growth and social prominence of these movements in the last decade is evidence that Christians in South Africa are seeking guidance, support and information to sustain and deepen their faith in the world of work. ${ }^{5}$

\section{The challenge and opportunity of ministry in the marketplace in South Africa}

South Africa has undergone some radical social and religious shifts since the dawn of participative democracy in 1994. The adopting of the new South African constitution ensured religious equality and freedom for all people in South Africa. A consequence of that is that Christianity is no longer afforded protected or special status in society. ${ }^{6}$ Before 1994 it was possible to defer Christian education to the National Education System, or to assume that evangelism would take place through public media broadcasts, or even that social ills could be resolved within the legal system by appealing to Christian moral values. Many Christians and churches in South Africa continue to function with a theology and worldview assuming that the work of evangelism, social transformation and the establishment of the principles of God's just and equitable kingdom can be left to the state or private enterprise. What are the theological reasons that lead to such a perspective? In addition to this, what opportunity is there for Christians and the church to be more faithful and effective in society?

\footnotetext{
4. One example will be sufficient to illustrate the growth of these movements. The
Unashamedly Ethical movement was launched in Cape Town in 2010. Within three Unashamedly Ethical movement was launched in Cape Town in 2010. Within three
years it has amassed over 20000 individual members and nearly 5000 corporate years it has amassed over 20000 individual members and nearly 5000 corporate
signatories. There are Unashamedly Ethical communities in each of the provinces in South Africa and signatories in 107 countries around the world. The founder of the movement, Graham Power (a Christian businessman in Cape Town), is confident that the movement will continue to grow in size and influence. (Power 2013)

5.See the recent article by Forster (2014a) for a thorough theological discussion of this issue. Please also refer to the Call42 survey for the original empirical data (Anon 2013d:42).

6.In the opinion of the authors it is to the church's benefit not to be favoured by the state any longer. There are two primary reasons for this: firstly, this allows for both critical prophetic distance from the publics of state and business, and secondly, it also challenges the church to take up its mission pastoral care within society, because it cannot delegate this role to the state or private sector. For a thorough discussion of this line of argumentation, see Bentley and Forster (2012:73-88).
} 


\section{A poorly developed theology}

One of the primary reasons why the church is missing the opportunity of mission and ministry in the marketplaces is because of ignorance. The most recent research on faith and work in South Africa has shown that pastors are not informed well enough regarding the challenges or the opportunities for kingdom work available to the members of their work environment (cf. Forster 2014a). The result is that members feel inadequately equipped for faithful Christian discipleship in the world of work. Rather, the research showed that the emphasis of most churches was focussed on equipping members to play a role in the local church's ${ }^{7}$ ministry. The result of this is that Christians lack the knowledge, skills and spiritual maturity necessary to function effectively as agents of God's mission and kingdom in the marketplace (Bosch 2011:67-70). Daily challenges such as economic corruption, sexual temptation, economic and social justice or the appropriate use of influence and power in the world of work are seldom dealt with from the pulpit, in church programs or in congregational prayer.

Mark Greene (2001:4-8) points out that a flawed theology of work has resulted in a distorted view of both work and economic production. This flawed theology is characterised by two views of the world of work as an ontologically corrupt and evil domain of life. In such extreme views, wealth and economic production are regarded as products of greed, mammon or evil. Any pleasure or profit derived from the world of work is thus evil and not in keeping with the will and purpose of God. On the other hand, extreme work is seen as a necessary burden to be endured and survived - it is an evil to be escaped in favour of the holiness of spiritual living that takes place in and through the life of the church.

There are of course those Christians who have a less binary view of faith and work. There are numerous examples of pietistic Christians who will hold prayer meetings, Bible studies or evangelistic outreaches at their place of work or amongst colleagues within working hours. However, since they lack a robust and well-rounded theology of work, they return to 'business as usual' (Hillman 2005:45) once the activity is concluded. ${ }^{8}$ These dualistic and sometimes pietistic practices can be criticised harshly by sceptics - even from within Christian circles. Moreover, they are seldom framed within a broader understanding of the missio Dei (Bosch 2011:363-364).

In recent years there have been some instances of 'full time' ministry workers such as corporate chaplains, working in businesses. ${ }^{9}$ However, such workers are very few and far between. In addition to this, it is questionable whether such practices are missiologically responsible and economically

7.Please see the section on the different forms of church in the marketplace in this article for a thorough discussion on the use of the word church in this context.

8.Another important contribution to a dualistic view of faith and work stems from an inadequate understanding of the public's notion and role of faith (Dreyer \& Pieterse 2010; Habermas 1991; refer to Smit 2007a).

9.See one South African example in Forster and Power (2011) sustainable in the world of work. As in the local congregation, Christians may stand back from ministry, considering it as something to be done by an appointed professional, rather than being the task of every disciple in their particular context.

The point is that millions of faithful Christians across the world are inadequately nurtured and supported within the local congregation with a robust theology of discipleship and mission in the world of work. Even fewer are adequately supported, nurtured and equipped for faithful mission and discipleship in the world of work itself. A great gap exists between what takes place on Sunday or within the ambit of the local congregation, and what members do with the rest of their time. Keller and Alsdorf (2012) write:

A job is a vocation only if someone else calls you to do it and you do it for them rather than for yourself. And so our work can be a calling only if it is reimagined as a mission of service to something beyond merely our own interests. (p. 19)

\section{A lack of creative and practical skill for ministry in the marketplace}

The Call42 research on faith and work in South Africa shows that a majority of Christians have questions about their calling and role in the world of work (Anon 2013b; Forster 2014a:3-4). However, the majority also indicated that they did not feel effectively or adequately equipped to respond as Christians to the challenges and opportunities they encountered in the world of work (Anon 2013c; Forster 2014a:3).

The Call42 research shows that while pastors and church leaders believe that their members should be using their skills, network of relationships and location in the marketplace to bring about transformation in society, their theological and discipleship focus is most frequently not in that area (Anon 2013c). Rather, the research shows that members are trained for functions and tasks related to the 'gathered church' such as congregational leadership, prayer ministries, leading groups within the congregation, sacrificial giving, worship and biblical interpretation. However, they are seldom taught how to deal with conflict, pressure, temptation, discernment or ethical dilemmas in their church life (Greene 2001:4-8; 2010:5-16).

On the other hand, Forster's research shows that companies and businesses, identifying themselves as operating from a Christian belief and value system, often address matters of social concern whether through Corporate Social Investment, or caring for the practical needs of their staff, or the communities in which they work (Forster 2014a:5). Yet, very few of these companies have a vision of the opportunities for exercising systemic influence in the realm of policy, ethics development or the generation and development of products and services, which have a social benefit that is in line with the values and ideals of God's kingdom as expressed in terms of the church's holistic mission (Bosch 2011:415-418; Johnson 2011:171-174; Keller \& Leary-Alsdorf 2012:19). 
Simply stated, it is essential for the church to rediscover a theology that can shape faithful worship and witness for every place and every day of the week. The contemporary church operates far too frequently with a dualistic theology that emphasises it as a gathered community in opposition to the kingdom of God, which covers all spheres of society. This is not a new debate as John Howard Yoder reminds us. The World Council of Churches spent many hours debating the deficiencies of an ecclesiocentric missiology, rather than a kingdom centred missiology (Yoder 2013:282). In recent years there has been a rediscovery of the somewhat radical views of Johannes Hoekendijk, which became prominent after the 1952 World Missionary Congress held in Willingen, Germany. On that occasion he argued that the dominant missionary theology of the 1900's, which was based on church planting and mission as an extension of the gathered community, needed a correction, namely that mission should be refocused on the biblical understanding of God's kingdom. This meant a less institution centred missional focus and paved the way for a more kingdom minded approach to God's mission in the various spheres of society both through the gathered and scattered church (Anderson 1999:297; Bosch 2006:177-178).

If the church were to rediscover and adopt such a view of mission, it would necessitate that Christians are prepared, equipped and inspired for ministries of service, transformation and influence in a variety of contexts in society. Being a teacher, doctor or lawyer could be a vocation of service, an act of ministry where the kingdom of God is established through the presence and work of the scattered church membership throughout the week.

\section{The opportunity}

As pointed out in the previous section, a kingdom focussed missiology understands that the church has a witness and work that extends beyond a particular building or certain times of the week, - which are frequently the predominant focus of the gathered congregation. Since God is active in every aspect of creation, the missional church should participate in the missio Dei [work of God], and thus also be active in bringing healing and transformation in all spheres of society. Missional theology has become increasingly aware that the church is already present and active in ministry in just about every aspect of society, as church members go to work, live in their communities and live out their faith in their everyday lives (Bosch 2011:400-402; Forster \& Power 2011:53-55). The challenge is to equip, mobilise and support its members to fulfil their calling as ministers and kingdom ambassadors in the marketplace, everyday and everywhere (Greene 2010: 17-23).

Therefore the lay-clergy gap also needs to be bridged (Greene 2010:1-3). In the words of Le Bruyns 2004):

To bridge the lay-clergy gap we need to change our basic image of who we are from 'Church' with a minister or two, referring to the Sunday gathering, to the People of God, who are all ministers, both gathered and scattered, Sunday and Monday. (p. 23)
According to Preece, Miyast and Kotiuga (2012):

there is huge potential for church growth in the next generation in the form of those who hunger for meaningful relationships in the workplace. Increasingly, multi-ethnic work environments in the West offer opportunity to enter into the lives of people from all nations. Two things need to happen if the church-work divide is to be bridged: rethinking the role of the church in supporting our workplace emissaries, and rethinking the role of work in motivating emissaries. (p. 3)

There is a growing awareness for the great need for spiritual and ethical guidance in the marketplace, but for this to happen individuals, companies, churches and marketplace ministry leaders have to be theologically formed, shaped and equipped for ministry in the wider world. They also have to be mobilised and sent for such work.

Ed Silvoso (2006) considers the reality that there is some nuance in the awareness and ability amongst Christians for ministry in the world of work. In this regard he distinguishes between four types of Christians in the marketplace. The first type he calls 'survivors' whose primary objective is to survive at work. Many Christians find themselves in this position - perhaps they are not in a 'dream job', or find themselves in a conflict ridden, dull or unfulfilling work environment. Such a perspective on work is not likely to have a missional view of work and therefore will have little or no effect for Christ in their workplace. The second type of Christian strives to live by Christian principles, yet their faith is largely a private matter with little or no impact on social, economic or political systems. Often persons in this category cannot see how their work life could be a means of faithfulness to Christ or a participation in the missio Dei. The third type of Christian seeks to discern the will of God for their entire life (including their work) and so seeks God's guidance and direction in work. Such a person will often seek to live faithfully and intentionally as a disciple of Christ in their work life. The fourth type of Christian takes their discipleship one step further and purposefully seeks to transform the society in which they live to match the values and ideals of God's kingdom (Silvoso 2006:148-150). Such a person may even choose to take on work of a certain kind in order to be able to transform or influence a social or political reality, or may stay in a position of work in spite of conflict or a lack of stimulation in order to obediently participate in the missio Dei.

In light of the argument being made in this article, the challenge that the church faces is to equip Christians to live their lives along the lines of Silvoso's third and fourth type as discussed above.

\section{Considering the different forms of church in the marketplace}

Up to this point this article has argued that the church should be awakened or re-awakened to a theology of work with a missional orientation towards the kingdom of God that has an impact upon every aspect of life. Leslie Newbigin (1991) 
captures this concept very clearly and succinctly when he writes:

It should become part of the normal work of the Church to equip its members for the exercise of priesthood in the many different areas of secular life, and in terms of the specific powers that rule those areas. (p. 84)

What is meant by the expression church $?^{10}$ This term is complex and refers to a number of theological concepts. It finds expression in different ways in society.

Dirkie Smit (2007b:61-68) suggests that there are three general forms of being 'the church'. These forms will be briefly described below and, in doing so, each of these different forms of church as agents of mission in the marketplace will be discussed:

- The church as a local congregation of Christian members.

For many Christians this is most likely to be their primary perspective of the church: a localised community of Christians organised around regular common worship. Philander (2011:177) points out that this is the place and social group that people often think of when they answer the question of where they go to church or what church they are members of.

What role can this 'form' of church play in being an agent of God's mission for the world of work? As Smit (2007b) rightly points out, this requires careful reflection. Firstly, it is important to recognise that the largest grouping of South Africa's Christians belong to African Initiated Churches. The last reliable census data showed that $48 \%$ of South Africa's Christian population fit into such church groups, ${ }^{11}$ with a further $31 \%$ belonging to other groups that include the mainline denominations (Nieman 2010:37). The church as congregation does have a role to play in South Africa if not simply by its sheer numbers in our population. Nieman (2010:37) comments that, 'the 23 main religious groupings, with a membership of $37,157,820$ in 2001 (84\% of the population) represent a potentially powerful voice and resource'.

Scholars argue that these local communities provide a great deal of social cohesion, faith identity that foster hope and, at times, even concrete expressions of hope such as feeding schemes, education, skills development and social care (Nieman 2010:37-44). In terms of this article's argument, we could say that this is certainly part of the work of missional engagement emerging from the local congregation. In a deeply religious nation such as South Africa, most communities can cite examples of individuals whose lives have been positively changed and transformed. Even examples can be cited of communities that have experienced transformation as a result of a local worshipping community's positive contribution,

10.This approach stems from Smit (2007b), however, it was adapted by Forste (2014b) and is further adapted for the purposes of this article's arguments. It thus uses similar terminology, but locates the theological emphasis in different areas uses similar terminology, but locates the theo
from the earlier uses by both Smit and Forster.

11.For a thorough theological discussion please see Hendriks and Erasmus (2005). which is active outside of their buildings' boundaries and their regular worship and meeting times.

Quite apart from the immeasurable spiritual value and the work of moral formation, added through local worshipping communities, there is another way in which such communities act as catalysts for ministry and mission in the world of work (Philander 2011:176-179).

The level of involvement in the local community as described above is characterised as first and second-generation involvement, to use the terminology of the social development scholar, David Korten (1990:117-118). First generation engagement refers to relief and charity work (soup kitchens, etc.), whereas second generation engagement refers to the work of empowering a community, often through projects such as skills development projects (sewing classes, trades, etc.).

We cannot deny that whilst this form of church has potential for great good, it also has the potential for harm. According to Smit (2007b:63) 'the Christian religion is also a dangerous power, and has been such and still is, in South Africa'. Many of the persons surveyed in Call42 showed that it was this form of church that focussed on its own survival, programs and needs, rather than training its members for ministry in their daily work and life (Forster 2014a:4-5).

John de Gruchy (1986) notes that at times in South Africa's history, church worship, teaching and liturgy has been the cause of the preventing the gospel from taking hold in society (cf. Smit 2007b:63). Smit (2007b:63) notes that this may not be the kind of contribution that theologians or religious leaders would like to see.

The question would thus be: How do we engage with this significant sector of Christian community in order to further the aim of an active and vibrant church that is engaged with every sphere of society, equipping its members for participation in the missio Dei?

- The church as institution, denomination and ecumenical body.

For many people the word church primarily refers to the organisational or institutional structures they identify with. When some people hear the word church they may think of the confessional community that they are part of (e.g. the Catholic, Orthodox or Methodist church). Philander (2011:177) notes that often this expression of church is what people would point to in answer to a collective question such as 'what does the church say about unemployment in South Africa'. It could also refer to collective groupings such as Evangelical Christians, African Initiated Churches or even more formal groupings such as ecumenical bodies (World Council of Churches or the World Communion of Reformed Churches). Smit (2007b:65) notes that we must take care not to confuse numerical prominence of a grouping with the social and theological contribution of that church. 
Simply knowing how many Methodists or Anglicans there are in South Africa does not tell us much about the respective groupings' contribution to society.

From a theology and development perspective this form of church would be understood to engage society from a third generation development strategy, namely to engage institutions' policies in society such as the church's mission and justice policies, the policies and laws of government, and the decisions and policies of regulatory bodies in society, et cetera (Korten 1990:119; Nieman 2010:8).

Forster's article (2015) on the church in South Africa since the dawn of participative democracy in 1994 discussed the demise of the ecumenical movement in South Africa. His research shows that ecumenical the church has been left somewhat weakened and voiceless in the new South African dispensation (Forster 2015:8). Unlike the period leading up to 1994, there is thankfully no longer a state church that can speak on behalf of the people, and sadly no longer a struggle church linked to a strong functional ecumenical body like the South African Council of Churches that represents the collective will and intentions of the churches in South Africa (Forster 2015:6-8). Smit (2007b:66) notes that the ecumenical movement that was 'strong during the apartheid years when many churches were committed to their common struggle against apartheid, has lost most of its appeal and influence'.

However, the demise of traditional ecumenical structures has led to new groupings in an attempt to fulfil this vital role of the witness and mission of the institutional church. Examples of such movements are the Religious Leaders Forum, South African Christian Leaders Initiative (SACLI), Unashamedly Ethical, Transformation Africa, and the re-birth of the South African Council of Churches. Not surprisingly, many denominations continue to be active in their prophetic work and witness in the public sphere and seek to empower their members to use their influence and resources to bring about social and policy change. One could site many wonderful examples of projects that denominations and groupings are involved in, which have a significant impact on society. However, there is scope for greater partnership, particularly as it relates to policy issues in society, matters of social justice, economic inequality and political accountability.

How could the denominational church be more strategic in using its membership to achieve the objectives and aims of the gospel and the kingdom? Many of the ministers in government, captains of industry and even persons engaged in crime and corruption are members of churches. What work could be done to transform society if the churches worked together in addressing some of the ills and evils that plague South Africa as a predominantly Christian nation?

- The church as believers, salt and light in the world.

Smit (2007b:68) notes that this is the third way in which people think of the church - as individual believers who are salt and light in the world, each involved in living out their faith on a daily basis in their own particular ways. This is a very important way in which the church can participate in being an agent and bearer of hope in society.

As mentioned earlier, the most recent research on how individual Christians feel about faith and work in South Africa was done by Forster (2014a). He draws on the qualitative research statistics of Call42. In the introduction to their research findings, Call42 explains why they felt motivated to conduct this research:

God's ultimate plan is to redeem all parts of creation back to Him [sic]. This includes hearts, minds, culture, nature, environment, government, law, media, craft, relationships, education etc. God has not called us out of the workplace, but he has specifically planted us in the workplace for a definite reason. It's important that the body of Christ understand [sic] that we are called to fill every position that exists; teachers, principals, political positions, industries ... every business that exist ... with a mission to manifest the Kingdom of God. (Anon 2013a)

Granted, not everyone would agree with the theological tenets in the above statement. Yet, such a focus on faith and work is laudable. It shows that some Christians have a clear understanding that they have a task and a role to play as agents of God's hope in society. However, the reality is that this perspective is a minority view amongst both South African Christians and many churches in South Africa. Forster's analysis (2014a:5) of the Call42 data showed the following (cf. Anon 2013d:1-2):

- Christians in South Africa are struggling to find significant meaning and purpose in their work.

- There is a hunger for a deeper focus on God and the principles of God's kingdom in every aspect of life (both those parts that are formed around the gathered church and the scattered church).

- It appears that churches struggle to adequately envision, equip and support Christians in the world of work. There is not sufficient training and support for business leaders and employees.

- A professional career matters to God and is useful for the purpose of advancing God's kingdom in society.

In an ideal situation the contribution of the church would be characterised as a fourth generation contribution, to use Korten's terminology (cf. 1990:11-132) once again. Fourth generation engagement is, according to Swart, Rocher \& Erasmus (2010):

akin to a social movement that makes extensive use of networks and people's independent mobilising actions to work for justice and people's self-actualisation in society. It is guided by an alternative vision in society that mobilises people to voluntary action. (p. 8).

Events such as the eviction of informal dwellers from land owned by the South African National Roads Agency in Lwandle and Nomzamo on the 04th of June 2014 serve as an example of the emergence of a people's movement around a cause for justice. When the public saw Murray Williams' pictures $(2014 \mathrm{a} ; 2014 \mathrm{~b})$ of people struggling to save their 
meagre belongings being exposed to the rain and cold, they were incensed. The public outcry put a halt to the injustice and even garnered apologies from government officials. It was the presence of Christians on the ground (particularly the work of Bishop Michel Hansrod), local ministers and members of churches who helped to bring the injustice to light and to bring about a tentative solution.

Gerald West challenged the church to recover the importance of people's theology in a paper he delivered at Stellenbosch University entitled 'People's theology, prophetic theology, and public theology in post-liberation South Africa' (in Claassens \& Birch 2015). In his paper he writes how biblical scholars and theologians have been engaging with social movements like Abahlali baseMjondolo [shack dwellers]. His challenge reminded of Albert Nolan's description (1988) of the South African church - the majority church - that we do not often think about:

The part of the Church that I am referring to is the oppressed part, the poor and the oppressed Christians of South Africa ... This cuts across all our Church denominations and includes leaders from various traditions. In fact, this part of the Church must now be, far and away, the majority of Christians in South Africa. (p. 211)

Indeed, this is the church in South Africa. It is largely poor, it is largely female and it is largely between the ages of 15-65. How can this form of church be awakened for the transformation of South African society? In which ways can this church be a bearer of Christian hope to the nation of South Africa?

\section{Conclusion}

This article has argued for the importance of a rediscovery of a theology of work that can empower and equip the church and individual Christians for effective and faithful ministry in the marketplace. The article showed that the influences of theological dualism, an unbalanced view of the clergy as primary agents of ministry and mission, and a structures-cantered view of ministry and mission detract from the possibility of the church's ministry in every sphere of society. Finally the three general theological views of the church in South Africa as presented by Smit and Forster were discussed and how the church could become an agent of mission and transformation in the marketplace in each of these three forms were considered. The conclusion of this article is that the church will need to revisit and rediscover its missional theology, refocuses its efforts on broader society as well as empowering and equipping its members for ministry in the marketplace in order to be faithful in partnering with God in the missio Dei.

\section{Acknowledgements}

This article wishes to honour the theological legacy of George Lotter by focussing on an important aspect of Christian life and witness, namely that of faith and work. Johann Oosterbrink, one of the authors of this article, was
Prof. Lotter's first doctoral student and would like to honour him for the fact that he was not only his Doctoral promotor but also a wonderful mentor, friend and in many ways, a role-model. In the 20 years after his graduation Prof. Lotter continued to play a major role in Dr Oosterbrink's life, firstly in his ministry as a pastor and later as a marketplace minister in the capacity as a specialist in organisational development in the business sector. Prof. Lotter has not only been a pastor and lecturer who gave guidance to congregants and students about their careers and life in general, but also spent several years in the business world and maintained a keen interest in the property market.

\section{Competing interests}

The authors declare that they have no financial or personal relationship(s) that may have inappropriately influenced them in writing this article.

\section{Authors' contributions}

Both authors worked on the article and shared the responsibility for research and writing equally.

\section{References}

Anderson, G.H., 1999, Biographical dictionary of Christian missions, Wm. B. Eerdmans Publishing, Grand Rapids, MI.

Anon., n.d.a, Unashamedly ethical, Home, viewed 13 September 2013, from http:// www.unashamedlyethical.com/Home/about.asp

Anon., n.d.b, News from the ALPHA SA Team, NICHE ALPHA COURSES, viewed 13 September 2013, from http://www.alphasa.co.za/p/niche-alpha-courses. html\#workplace

Anon., n.d.c, What is halftime, viewed 13 September 2013, from http://www. halftimesa.co.za/what_is_halftime.html

Anon., 2013a, Introduction to Call42, Call 42, viewed 13 September 2013, from http:// www.call42.co.za/introduction/

Anon., 2013b, Survey: Issues related to the concept of calling, Call42, Stellenbosch.

Anon., 2013c, Survey: Top challenges, Call42, Stellenbosch.

Anon. 2013d, The survey, Call 42, viewed 13 September 2013, from http://www. call42.co.za/call42-survey/

Anon., 2014, General household survey 2013, Statistics South Africa, Pretoria, viewed 11 June 2015, from http://www.statssa.gov.za/publications/P0318/P03182013. pdf

Batchelor, P., 2008, Light, salt and the world of business: Why Christians must stand against corruption, The Lausanne Movement, South Hamilton, MA.

Bentley, W. \& Forster, D.A., 2012, Between Capital and Cathedral: Essays on ChurchState relationships. Research Institute for Theology and Religion, University of South Africa, Pretoria.

Bosch, D.J., 2006, Witness to the World: The Christian Mission in theological perspective, Wipf and Stock Publishers, Eugene, OR.

Bosch, D.J., 2011, Transforming mission: Paradigm shifts in theology of mission, Orbis Books, Maryknoll, NY.

Claassens, J. \& Birch, B., 2015, Restorative readings: Old Testament, ethics, human dignity, Wipf \& Stock Publishers, Eugene, OR.

Costa, K., 2007, God at work: Living every day with purpose, Continuum, London.

De Gruchy, J.W., 1986, Cry justice! Prayers, meditations, and readings from South Africa, Orbis Books, Maryknoll, NY.

Dreyer, J.S. \& Pieterse, H.J.C., 2010, 'Religion in the public sphere: What can public theology learn from Habermas's latest work?', HTS Teologiese Studies/Theological Studies 66(1), Art. \# 798, 7 pages. DOI: 10.4102/hts.v66i1.798

Forster, D.A., 2014a, 'Called to work: A descriptive analysis of Call42's research on faith and work in South Africa', Koers - Bulletin for Christian Scholarship 79(2), Art \#2143, 9 pages. http://dx.doi.org/10.4102/koers.v79i2.2143.

Forster, D.A., 2014b, 'Mandela and the methodists: Faith, fallacy and fact,' Studia Historiae Ecclesiasticae, suppl. ser. 40, 87-115.

Forster, D.A., 2015, 'What hope is there for South Africa? A public theological reflection on the role of the church as a bearer of hope for the future', HTS Teologiese Studies/Theological Studies 71(1), Art. \#2814, 13 pages. http:// dx.doi. org/10.4102/hts. v71i3.2814 
Forster, D.A. \& Power, G., 2011, Transform your work life, Russell Media, Boise, ID.

Greene, M., 2001, Supporting Christians at Work, London Institute of for Contemporary Christianity, London.

Greene, M., 2010, The great divide, London Institute of for Contemporary Christianity, London.

Habermas, J., 1991, The structural transformation of the public sphere: An inquiry Into a category of bourgeois society, MIT Press, Cambridge, MA.

Hendriks, J. \& Erasmus, J., 2005, 'Religion in South Africa: 2001 population census data', Journal of Theology for Southern Africa 121, 88-111.

Hillman, O., 2005, The 9 to 5 window, Regal Books, Ventura, CA.

Johnson, B., 2011, Transforming society: A framework for fixing a broken world Indaba Publications, San Francisco, CA.

Keller, T.J. \& Leary-Alsdorf, K., 2012, Every good endeavor: Connecting your work to God's work, Dutton, New York.

Korten, D.C., 1990, Getting to the 21st century: voluntary action and the global agenda, Kumarian Press, West Hartford, CT.

Le Bruyns, C., 2004, 'Marketplace Ministry', in D. Claydon (ed.), Occasional Paper no. 40, hosted by the Lausanne Committee for World Evangelization, Pattaya, Thailand, September 29-October 5, pp. 3-59.

Newbigin, L., 1991, Truth to tell: The gospel as public truth, SPCK, London.

Nieman, A., 2010, 'Churches and social development in South Africa', in I.W. Swart, H. Rocher, J. Erasmus \& S. Green (eds.), Religion and social development in postapartheid South Africa, pp. 37-44 SUN Press, Stellenbosch.

Nolan, A., 1988, God in South Africa: The challenge of the gospel, William B. Eerdmans Publishing, Grand Rapids, MI.

Philander, N.C., 2011, 'Die rol van die kerk as een van die instellings in die samelewing wat mense moreel vorm', Dutch Reformed Theological Journal/Nederduitse wat mense moreel vorm', Dutch Reformed Theol
Gereformeerde Teologiese Tydskrif 52(1\&2), 174-185.

Power, G., 2013, Interview with Graham Power founder of the Unashamedly ethical movement and chairman of the Power Group of companies.
Preece, G., Miyashita, A. \& Kotiuga, W., 2012, Truth and the workplace: Sacred-secular divide, The Lausanne Global Conversation, viewed 13 September 2014, from $\mathrm{http}: / /$ conversation.lausanne.org/en/resources/detail/12586\#.VOGxGhaOfrw

Silvoso, E., 2006, Anointed for business, Regal Books, Ventura, CA.

Silvoso, E., 2007, Transformation: Change the marketplace and change the world, Regal Books, Ventura, CA.

Smit, D.J., 1996,' Oor die kerk as 'n unieke samelewingsverband', Tydskrif vir Geesteswetenskappe 2(36), 119-129.

Smit, D., 2007a, 'Notions of the public and doing theology', International Journal of Public Theology 1(3), 431-454. http://dx.doi.org/10.1163/156973207X231716

Smit, D.J., 2007b, Essays in public theology: Collected essays 1, AFRICAN SUN MeDIA, Stellenbosch.

Spada, D. \& Scott, D., 2011, Monday morning atheist: Why we switch God off at work and how you fix it, Worklife Press LLC., Atlanta, GA.

Swart, I.W., Rocher, H. \& Erasmus, J., 2010, Religion and social development in post apartheid South Africa: Perspectives for critical engagement, SUN Press, Stellenbosch.

Van der Merwe, N., Nel, C., Pohl, K. \& Stadler, R., 2010, What does god know about business? Making the right decisions in tough times, CreateSpace Independent Publishing Platform, New York, NY.

Volf, M., 2005, God at work, Word \& World 25(4), 381-393.

Williams, M., 2014a, 'Lwandle eviction battle: PICS', Cape Argus, viewed 13 September 2013, from http://www.iol.co.za/news/crime-courts/Iwandle-eviction-battlepics-1.1697669?showComments=true\#.U_szlBaOflo

Williams, M., 2014b, 'We'll never see evictions like that again', Cape Argus, viewed 13 September 2013, from http://www.iol.co.za/capeargus/we-ll-never-seeevictions-like-that-again-1.1699973\#.U5Xc6xa0flo

Yoder, J.H., 2013, Theology of mission: A believers Church perspective, InterVarsity Press, Downers Grove, IL. 